\title{
Circulating MicroRNA-21-3p: A Potential Biomarker for Peste-des petits ruminants Virus in Naturally Infected Goats
}

\author{
Preeti P. Bramhapurkar ${ }^{1}$, Prabhakar A.Tembhurne ${ }^{1 *}$, S. Chandra Sekar ${ }^{3}$, \\ D. Muthucheven ${ }^{3}$, Sharvan Sehrawat ${ }^{4}$, Prashant Tarale ${ }^{1}$, \\ Vijay.C.Ingle ${ }^{1}$ and Rajeev Kaul ${ }^{2}$
}

${ }^{1}$ Department of Veterinary Microbiology and Animal Biotechnology, Nagpur Veterinary College, Maharashtra Animal and Fishery Sciences University, Nagpur-440006, Maharashtra, India

${ }^{2}$ University of Delhi, South Campus, New Delhi, India

${ }^{3}$ Indian Veterinary Research Institute (IVRI), Mukteshwar, Nainital, Uttarakhand, India

${ }^{4}$ Indian Institute of Science Education and Research, Mohali, Punjab, India

*Corresponding author

\begin{abstract}
A B S T R A C T
\section{Keywords}

PPRV, serum miRNA, miR-21-3p, viral pathogenesis, bBomarker, Disease progression

Article Info

Accepted:

10 July 2020

Available Online:

10 August 2020

Micro RNAs have been recognized to play vital role in viral replication and pathogenesis. Circulatory miRNAs found in body fluid in stable, cell free form may be correlated with different stages of Peste des Petits Ruminanats (PPR) infection.The present study was focused to profile expression of circulatory miR-21-3p in serum of PPRV infected and apparently healthy goats in natural condition. The identification of suitable endogenous miRNA in serum samples and miRNA-21-3p profiling was performed using quantitative real time PCR (qRT-PCR) in 20 representative samples of PPRV infected goats from four different outbreaks (Bondri, Nagpur, Umred and Yawatmal district) in Maharashtra state, India during year January 2017-December 2017. The miR-16 was identified as endogenous control while expression of miR-21-3p was significantly elevated in all 20 serum samples of PPRV infected goats than control group with fold change ranging from 1.99 to 31.77 ( $p$ value $\geq 0.05$ ) in PPR infected samples. Relative fold change values varied in infected samples corresponding to symptoms shown by infected animals. We predicted miR-21-3p may be used as indicator for stage of PPRV infection and as promising biomarker for PPRV disease progression.
\end{abstract}

\section{Introduction}

Micro-RNAs are important family of noncoding small RNAs having length ranging from 19-24 nucleotides, generated from endogenous hairpin shaped transcripts. They control the flow of genetic expression by either controlling translation or stability of mRNA (1). MicroRNA has been acting in various mechanisms viz. propagation of viruses, cellular antiviral responses. They are also found in various biofluids in circulation viz. urine, saliva, plasma, serum etc. Immune as well as non-immune cells could secrete 
miRNAs into extracellular environment. Presence of circulating miRNAs in the serum and plasma samples were first reported in 2008(2). Circulatory micro RNAs are remarkably stable in harsh conditions of $\mathrm{pH}$, temperature, salt concentration, boiling, and freeze thaw cycles etc (3). Studies have demonstrated direct correlation between level of circulating miRNAs and diseases progression in infectious disease of veterinary importance like in foot and mouth disease, bovine viral diarrhea(4).

Peste des petitsruminanats (PPR) disease is a viral disease that affects sheep and goats. PPR disease is caused by an enveloped single stranded negative-sense RNA virus, belongs to the genus of Morbillivirus within the family Paramyxoviridae of Mononegavirales order. PPRV infection may end with high morbidity up to $100 \%$ and mortality of $80 \%$ (5). PPR incidence shows a wave pattern and outbreaks have been reported throughout the year in different states of India (5).

The emergence of deep sequencing technology has greatly revolutionized the field of miRNA research. Several studies have utilized this technology for global profiling of miRNAs associated with viral infections and other chronic manifestations $(6,7,8)$. Recent studies involving host-virus interaction in PPR have discovered critical transcription factors modulating innate immune response (9).

Integrated micrornome and proteomic study for PPR infected experimental sheep and goat for lung and spleen was recently performed. Among the six putative differentially expressed miRNA, miR-21-3phas shown significant differential expression in spleen and lung tissue, presumed to regulate immune response genes (10). However, circulatory miRNA profile for PPRV disease has not been reported yet.
In natural infection circulatory miRNA can be evaluated as biomarker for PPRV replication, pathogenesis and progression of disease, hence the present study was designed to evaluate the expression of circulatory miR$21-3 p$ in serum of naturally infected goats for Peste des petitsruminanats virus.

\section{Materials and Methods}

\section{Sample collection}

The collection of samples were performed as per Institutional Animal Ethics Committee (IAEC) approved vide no. NVC/IEAC/3769/2018, Dated 25/01/2018, Resolution No. 11. Samples were collected from four different outbreaks (Bondri, Nagpur, Umred, Yawatmal) in Maharashtra state, India during year 2017. Nasal swabs and serum sample from PPR suspected animals and blood smears for bacterial investigations were also collected. Nasal swabs as well as serum samples from apparently healthy non-vaccinated goats were collected as control group for miRNA expression profiling. A total of 33 nsal swab samples collected during these outbreaks from sick animals and 5 were collected from apparently healthy animals. All samples were tested for PPRV infection.

\section{Differential diagnosis}

Differential diagnosis was done to rule out CCPP (Contagoius Caprine Pleuropneumonia) H.S (Hemorrhagic septicemia), Goat Pox and Contagious ecthymaon the basis of clinical symptoms observed in infected animals. Secondary bacterial infections like pneumonia caused by Pasturella mutlocida was ruled out by blood smear examination while pneumonia caused by Klebsiella pneumoniae was ruled out by PCR for species specific uge gene (F-5'-TCT TCA CGC CTT CCT TCA CT-3'; R-5'-GAT CAT CCG GTC TCC CTG TA-3') (11). 


\section{Confirmation of PPRV}

Confirmation of PPRV was carried out by M gene based reverse transcriptase PCR using M gene specific primers. Nasal swabs of PPRV suspected animals were processed for RNA isolation by Trizol reagent method (TRIZOL reagent Cat \#T9424), followed by cDNA synthesis as per manufacturer protocol using High capacity cDNA synthesis Kit (Applied biosystems, USA, Cat no\#4374966). The PCR was carried out using $M$ gene specific primers as published by Balamurgan (12) and were analyzed by $2 \%$ agarose gel electrophoresis using 50bp DNA ladder (GeneRuler 50 bp DNA Ladder, ThermoScientific, USA).

\section{miRNA Isolation and Reverse Transcription}

Serum samples from representative positive animals as well as PPR negative animals were processed for total RNA isolation using miRCURY ${ }^{\mathrm{TM}}$ RNA Isolation Kit - Biofluids cat. no. \#300112 as per manufacturer's protocol. After, $200 \mu 1$ serum sample used for miRNA isolation. The RNA isolated from the serum samples was quantified using Quantus $^{\mathrm{TM}}$ Fluorometer (Promegacorporation, USA). Then, used 150ng RNA for reverse transcription using miCURY LNA RT Kit Qiagen (cat. no. 339340).

\section{qPCR and Normalization with Suitable Endogenous Control}

Identifying endogenous control for present study was a tricky task. We tried U6, celmiR-39 and miR-16 as an endogenous control with the target miR-21-3p. U6 is widely used as an endogenous control for miRNA profiling but it is well stable with tissue associated miRNAs rather than circulatory miRNAs. Initially, C. elegans microRNA, synthetic cel-miR-39-3p RNA (Cat \#194029) was spiked @ $0.002 \mathrm{fmol} / 200 \mu \mathrm{l}$ of serum as 'a spiked in 'control, and $1 \mu \mathrm{g}$ carrier RNA (tRNA) during RNA isolation as per recommendation of kit (ExiqonmiCURY LNA Universal miRNA PCR). The cel-miR39 primer mix (Exiqon, Cat no \# 190329) was used for detection of spike in control. Expression profiling of miR-16 (Endogenous Control) and miR-21 (Target) was done using miRCURY LNA ${ }^{\mathrm{TM}} \mathrm{SYBR}^{\circledR}$ Green PCR kit (Cat no.339346, Qiagen, USA) for qPCR and primers (miRCURY LNA ${ }^{\mathrm{TM}}$ miRNA Primer Assay, Cat no.YP02108895 for miR-21-3p, Cat no, YP02114063 for miR-16b, Qiagen, USA) in Light Cycler 96, Roche, Germany.

Approximately $200 \mu \mathrm{l}$ of serum volume was used for isolation of RNA, and downstream volume was adjusted to $4 \mu \mathrm{l}$ for cDNA synthesis in qRT-PCR amplification plotthe amount of RNA to be used was optimized to $150 \mathrm{ng}$ for cDNA synthesis, and cDNA so synthesized was diluted 1:10 for PCR. Theamplicons of the miRNAs were validated by the 3\% Agarose gel electrophoresis which was observed as a very specific band in realtime qPCR. The gel was photographed under SYBR Green filter using gel-documentation system (Biozen lab, India).

\section{Data and statistical Analysis}

Data analysis was done using widely used expression fold change method i.e. $2^{\wedge}-\Delta \Delta \mathrm{Cq}$ (13). It is used for relative fold change expression in infected and control samples. In current study, expression profile of miR-21$3 p$ and miR-16 were analyzed by taking the $\mathrm{Cq}$ values of qRT-PCR from infected \& control groups. Data of qRT- PCR was analyzed for $\Delta \mathrm{Cq}$ value analysis in which average $\mathrm{Cq}$ value of triplicate of each sample was taken, $\Delta \Delta \mathrm{Cq}$ value calculated by subtracting $\Delta \mathrm{Cq}$ value of infected sample from $\Delta \mathrm{Cq}$ of control samples. Expression fold change was calculated using formula $\left(2^{\wedge}-\right.$ 
$\Delta \Delta \mathrm{Cq})$. The data were presented as the mean values standard error of mean $( \pm$ SEM). Statistical analysis was performed using oneway analysis of variance (ANOVA) with Tukey's post-hoc test. P-values which were less than 0.05 were considered significant.

\section{Results and Discussion}

\section{Differential diagnosis \&Confirmation of PPRV}

Based on clinical symptoms, we ruled out possibilities of CCPP in infected animals as animal showed pneumonia as well as diarrhea. None of the animal had scabby mouth Orf i.e contagious ecthyma. The blood smears on leishman's staining were negative for any Pasturella spp. Pneumonia caused by Klebsiella pneumoniae was investigated using PCR which revealed that our samples were negative for presence of Klebsiella pneumoniae (Supplementary Figure. 1). All samples from sick animals showed 124bp M gene specific PCR amplicons, whereas none of the apparently healthy samples showed any amplification for M gene in PCR (Figure1).

miRNA isolation and qRT-PCR standardization and Normalization with Suitable Endogenous Control

Among the tested samples, 20 representative PPR positive serum samples were further processed for miRNA profiling. The total RNA concentration variability per sample was adjusted to a unique concentration for all the assays for accurate predictions of the expression profile. The optimization parameters like concentration of RNA input, house-keeping reference miRNA etc was carried out. Initially, Serum volume $(200 \mu 1))$ taken for isolation of RNA and downstream volume adjusted $4 \mu \mathrm{l}$ for cDNA synthesis in qRT-PCR amplification plot. The assays using different miRNAs (miR-16 \& miR-21) were performed that showed amplification as early as 16- 20 cycles of qRT-PCR in reaction upto 45 cycles.

Initially, C. elegans microRNA, synthetic celmiR-39-3p RNA (Cat \#194029) was spiked @ $0.002 \mathrm{fmol} / 200 \mu \mathrm{l}$ of serum as a spiked in control and $1 \mu \mathrm{g}$ carrier RNA (tRNA) during RNA isolation as per recommendation of kit (ExiqonmiCURY LNA Universal miRNA PCR). The cel-miR-39 primer mix (Cat no \# 190329) was used for detection of spike in control. During the qRT-PCR, the data showed aberrant amplification of cel-miR$39-3 p$ above 45 cycles as spike in endogenous control in serum samples. So it was not considered for further analysis.

miR-16 have been used as endogenous control to normalize relative expression for miRNA expression profiling in serum samples (14). We further evaluated the applicability of miR-16, as internal reference control which showed stable amplification and melt curves for three technical triplicates for control and infected serum sample. Hence we used miR-16 as an endogenous control and normalizer in present study for serum miRNA profiling.

\section{Confirmation of miR-16 and miR-21 on Agarose Gel Electrophoresis}

We have tested the miR-16 \&miR- 21-3p for its amplification as well as melting peak analysis. The data analysis showed a single melting peak for miR-16 \&miR- 21-3p each. Further we want to confirmed it by running the amplified miR-21 and miR-16 products of qPCR in 3\% Agarose gel for their size and to check any non-specific amplification with DNA ladder (50bp Gene ruler, Thermo Scientific \#SM037). The gel was photographed under SYBR Green filter using gel-documentation system. A single, specific, clear bands size ranging between 50-60bp bands were observed, depicted in figure 2 . 
Expression profiling of mir-21-3p in PPRV infected serum samples

Twenty out of 33 representatives PPR confirmed samples and five confirmed PPRV negative (apparently healthy samples) were analyzed for miR-16 and miR-21 expression profiling using three technical triplicates for each sample in qRT-PCR (Figure 3). Expression fold change values were ranging from 1.9 to 31.77 in 20 representative samples viz. from sample no.I3 to I6 (Umred) expression fold change seen in range between 1.9 to 6.2 while I6 showed highest fold change among all samples i.e. 31.77 ( $p$ value $\geq$ 0.005). Sample I7 to I16 (Bondri) showed fold change which range from 1.9 to 23.12 ( $\mathrm{p}$ value $\geq 0.005)$ where $\mathrm{I} 12$ showed highest elevation in fold change. Sample no I17 to I19 (Yawatmal) fold change was in range from 4.8 to 10.48 ( $\mathrm{p}$ value $\geq 0.005$ ) and for sample I20 to $\mathrm{I} 22$ ( $\mathrm{p}$ value $\geq 0.005$ ) (Nagpur) it was ranging from 1.9 to 25.4 ( $\mathrm{p}$ value $\geq 0.005$ ).

\section{Correlating miR-21-3p expression with clinical symptoms in infected animals}

The data obtained for relative expression for miR-21-3p revealed that the infected animals from different outbreak regions and also among the outbreak area shows varied fold change value for miR-21-3p. This varied expression level might be attributed with clinical symptoms, stage of infection and response of host against the PPR virus infection. Hence we attempted to correlate the relative fold change data for miR-21-3p with clinical condition on infected animals (Table 1). Upon analysis, it was found that the samples showing the highest elevation in miR-21-3p had higher body temperature $106.4^{\circ} \mathrm{F}$ for sample I6 with severe clinical symptoms of PPR. Likewise for other samples, it was found that there was a direct correlation with the fold change value for miR-21-3p and the severity of clinical symptoms in infected animals. We also followed the progression of disease status of infected animals and there were reported death owing to PPR infection.

miRNAs has emerged as an important class of regulatory RNAs playing critical role in hostpathogen interactions (15). miRNA have been identified to play essential role in the pathology of several respiratory viruses including promoting development and progression of viral infection. miR-142have been reported to suppresses replication of Eastern Equine Encephalitis virus (15) and miR-122 were found to enhances replication of Hepatitis C virus (16). In HIV-1 infection, expression of several host miRNAs such asmiR-122, miR-373, miR-370 and miR-297 were elevated whilemiR-17-92 cluster expression were suppressed via some unexplored mechanism (17). miRNA may serve as therapeutic and prognostics biomarker for respiratory viral infectious disease (18).

Circulatory miRNAs are of great importance for their utility as biomarkers, and needs to be investigated in various types of viral infection (19). Current study was planned to analyze miR-21 expression profile in natural infection of PPRV in goats from their serum samples. Our clinical findings were correlating with the typical symptoms recorded by various researchers (20). In our study we have also investigated clinical picture for differential diagnosis with other disease like CCPP, Goatpox, Pneumonia of H.S and Klebsiella spp origin.

Our study shows that the serum miR-21 expression was up-regulated upto 1.9 to 31.77 fold in infected animals. The up-regulation of expression correlated with the progression of disease. In another study the PPRV infected animals showed miR-21-3p was up-regulated in spleen upto 2.35 fold in goats, 1.44 fold changes in sheep, whereas in lung it was highly expressed upto 5.82 in goats and 1.75 
fold change in sheep in experimental PPR infections (10). The present study conducted on animals during natural disease outbreaks clearly showed that some of the animal exhibit higher temperature and miRNA-21-3p elevated up to 31.77 fold expressions directly correlated with higher body temperature.

Table.1 Correlation between clinical symptoms observed for PPR infected animals and fold change for miR-21-3p expression

\begin{tabular}{|c|c|c|c|c|c|}
\hline $\begin{array}{l}\text { Outbreak } \\
\text { Region }\end{array}$ & Samples & $\begin{array}{c}\text { Body } \\
\text { temperature }\end{array}$ & Clinical Symptoms & $\begin{array}{l}\text { miR-21-3p } \\
\text { expression } \\
\text { fold change }\end{array}$ & $\begin{array}{c}\text { Disease } \\
\text { progression }\end{array}$ \\
\hline \multirow[t]{4}{*}{ Umred } & $\mathrm{I} 3$ & $106^{\circ} \mathrm{F}$ & Nasal discharge, diarrhoea & 1.64 & Survived \\
\hline & I4 & $103^{\circ} \mathrm{F}$ & Coughing, diahrreoa & 1.54 & Survived \\
\hline & I5 & $106^{\circ} \mathrm{F}$ & $\begin{array}{l}\text { Oral ulceration, coughing, nasal } \\
\text { discharge diarrhea, high fever }\end{array}$ & 6.28 & Death \\
\hline & I6 & $106.4^{\circ} \mathrm{F}$ & $\begin{array}{l}\text { Coughing, sneezing, nasal discharge, } \\
\text { lacrimation, oral ulceration, diarrhea, } \\
\text { high fever }\end{array}$ & 31.78 & Death \\
\hline \multirow[t]{10}{*}{ Bondri } & I7 & $104^{\circ} \mathrm{F}$ & Nasal discharge, coughing, diarrhoea & 1.61 & Survived \\
\hline & I8 & $104.6^{\circ} \mathrm{F}$ & Nasal discharge,coughing, diarrhoea & 4.11 & Survived \\
\hline & I9 & $103.4^{\circ} \mathrm{F}$ & Nasal discharge,coughing, diarrhoea & 1.05 & Survived \\
\hline & I10 & $104^{\circ} \mathrm{F}$ & Nasal discharge, coughing ,diarrhoea & 5.31 & Death \\
\hline & I11 & $106^{\circ} \mathrm{F}$ & $\begin{array}{l}\text { Coughing, diarrhoea, high fever, oral } \\
\text { ulceration,nasal discharge }\end{array}$ & 8.82 & Death \\
\hline & $\mathrm{I} 12$ & $106.8^{\circ} \mathrm{F}$ & $\begin{array}{l}\text { Coughing, diarrhoea, lacrimation, high } \\
\text { fever,ulceration, diarrhoea }\end{array}$ & 23.92 & Death \\
\hline & I13 & $104^{\circ} \mathrm{F}$ & Coughing, diarrhoea & 3.97 & Survived \\
\hline & I14 & $103.6^{\circ} \mathrm{F}$ & Coughing, diarrhoea & 2.08 & Survived \\
\hline & I15 & $102.8^{\circ} \mathrm{F}$ & $\begin{array}{l}\text { Coughing, diarrhoea, nasal discharge, } \\
\text { oral ulceration }\end{array}$ & 5.86 & Death \\
\hline & $\mathrm{I} 16$ & $106^{\circ} \mathrm{F}$ & $\begin{array}{l}\text { Coughing, diarrhoea, high fever, oral } \\
\text { ulceration, nasal discharge }\end{array}$ & 9.13 & Death \\
\hline \multirow[t]{3}{*}{ Yavatmal } & I17 & $104.7^{\circ} \mathrm{F}$ & $\begin{array}{l}\text { Coughing, oral ulceration, Salivation, } \\
\text { recumbency, nasal discharge }\end{array}$ & 10.48 & Death \\
\hline & I18 & $105^{\circ} \mathrm{F}$ & $\begin{array}{l}\text { Nasal secretion, coughing, diarrhoea, } \\
\text { nasal discharge, oral ulceration }\end{array}$ & 6.77 & Death \\
\hline & I19 & $104^{\circ} \mathrm{F}$ & $\begin{array}{l}\text { Nasal secretion, Diarrhoea, oral } \\
\text { ulceration }\end{array}$ & 4.86 & Death \\
\hline \multirow[t]{3}{*}{ Nagpur } & $\mathrm{I} 20$ & $106^{\circ} \mathrm{F}$ & $\begin{array}{l}\text { Oral ulceration, coughing, nasal } \\
\text { secretion, diarrhea, high fever }\end{array}$ & 25.46 & Death \\
\hline & $\mathrm{I} 21$ & $103^{\circ} \mathrm{F}$ & Nasal Discharge, coughing & 1.85 & Survived \\
\hline & $\mathrm{I} 22$ & $103^{\circ} \mathrm{F}$ & $\begin{array}{l}\text { Nasal discharge, lacrimation, oral } \\
\text { ulceration, diarrhoea }\end{array}$ & 7.89 & Death \\
\hline
\end{tabular}


Fig.1 Gel-electrophoresis for PPR M gene specific PCR. PCR amplicons were run on 2\%

Agarose gel and photographed with Geldoc system (Biozen, India). M-50 bp DNA ladder, Samples (I5, I12, I18, I21, I7, I14, I19, I20, I21, I22), +ve-Positive control, -ve-Negative control
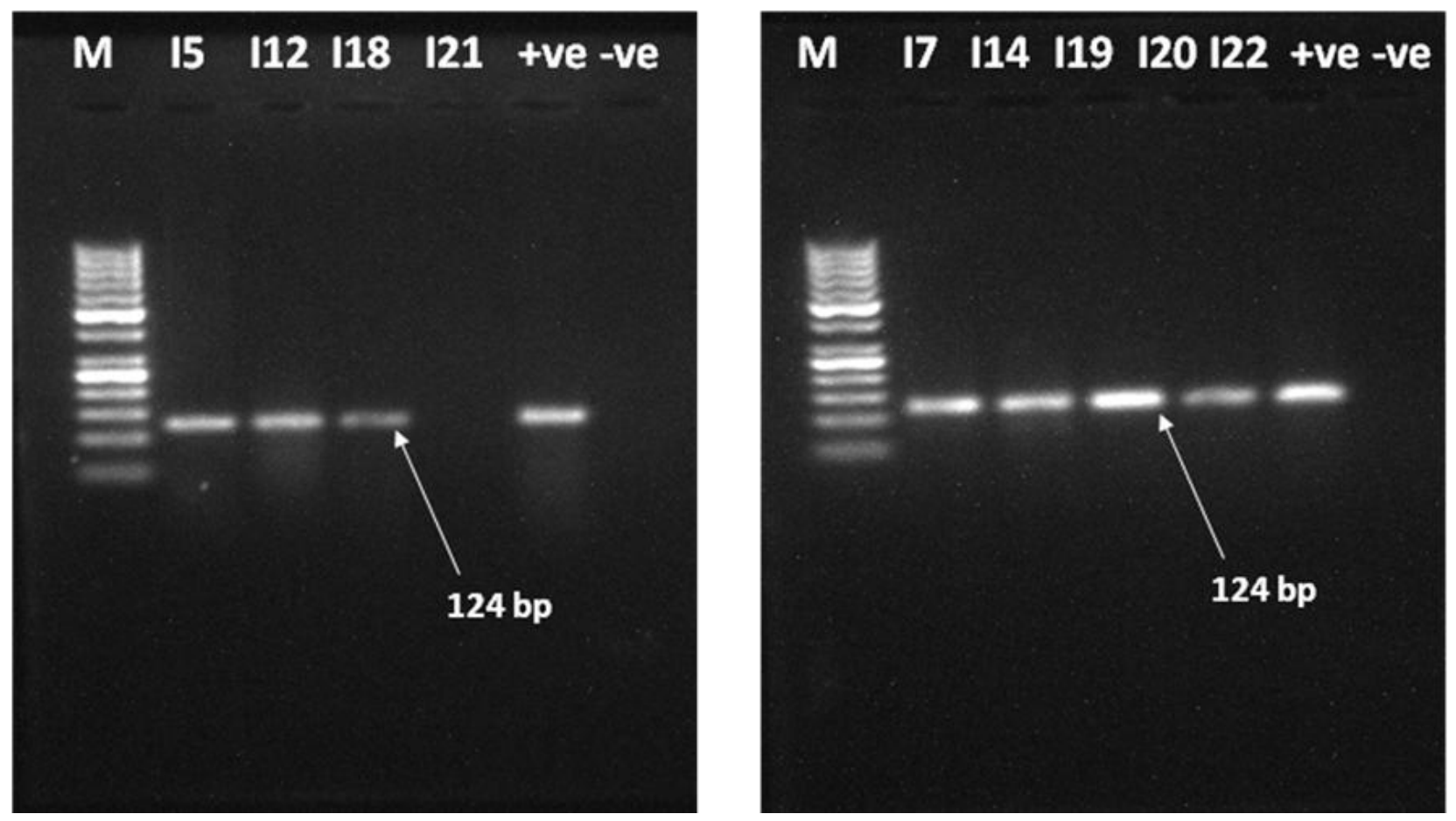

Fig.2 Relative fold change expression for miR-21-3p in PPR infected samples.miR-16 used as endogenous control to normalize data. Graph drawn using graph pad prism 7.02 showing miR21-3p (relative fold change) values and error bars added showing standard error of mean (SEM) for each infected sample $(* \mathrm{p}<0.05, * * * \mathrm{p}<0.001, * * \mathrm{p}<0.01)$

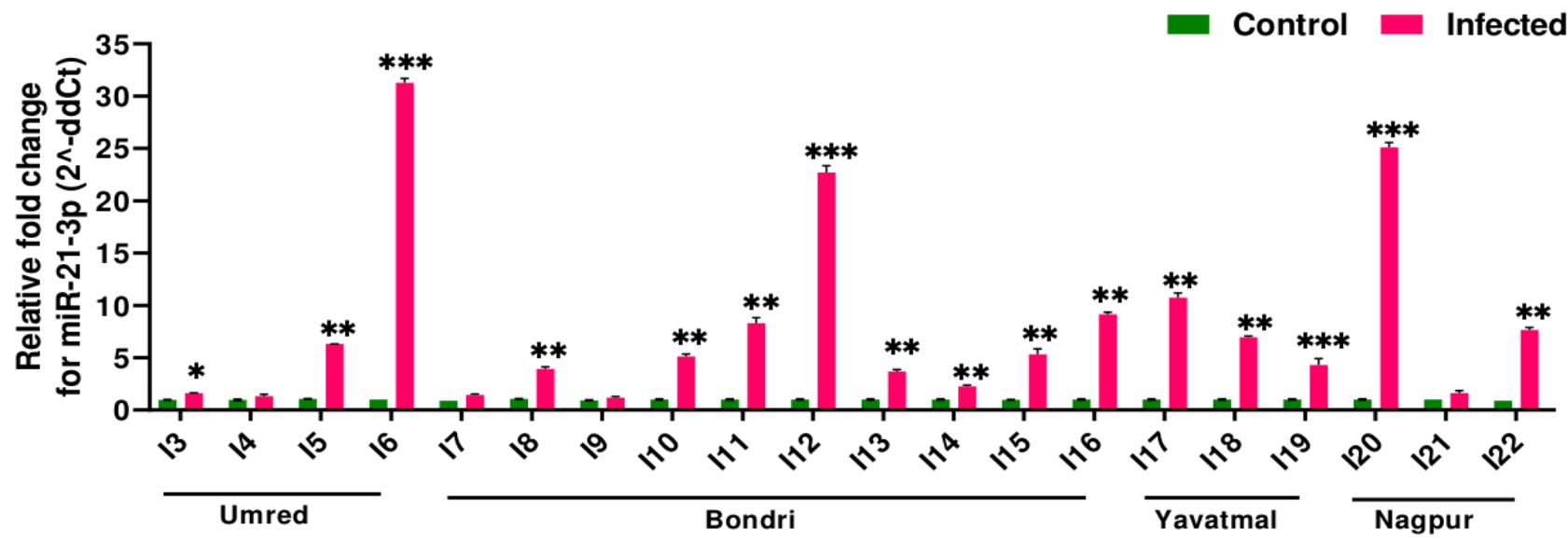


Fig.3 Gel-electrophoresis of target miR-21-3p and endogenous control miR-16 on 3\%Agarose gel (M-50 bp DNA ladder, miR-16, miR-21-3p, NTC-non template control)

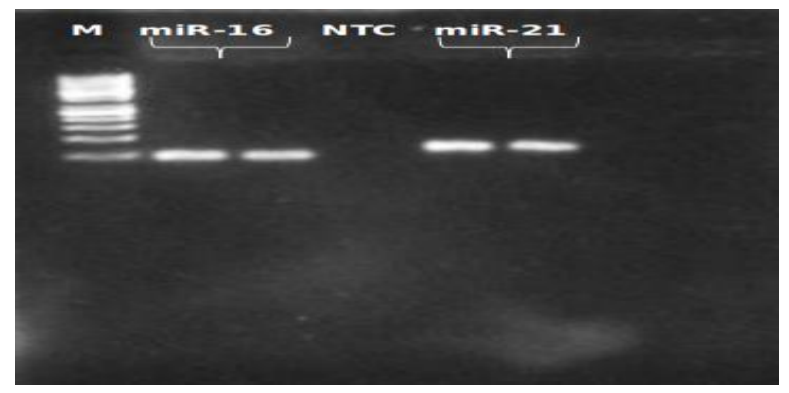

The clinical stage and miRNA expression upregulation indicates that this miRNA could serve as additional parameters for further prognosis of disease. miR-21-3p has been known to be mediator of inflammatory response in macrophages, and simultaneously promote inflammation in non-hematopoietic cells (10). Infection of hepatocytes with HCV and $\mathrm{HBV}$ was recently reported with elevated level of miR-21 level in correlation with increased viral replication (21). miR-21 also shown to promote host-virus interaction in favor of the virus $(21,22)$.In another study, the miR-122 was also found to be responsible for determination of cell tropism of $\mathrm{HCV}$ and involvement in propagation of virus (23). miR-21-3p is among the most studied miRNAs that considered to play an important role in the pathology of various cancers as well as viral infection when aberrantly expressed $(21,24)$. The virus might be using this miRNA for its pathogenesis or due to the immune suppression or host might be expressing this miRNAs as counter measures against viral replications needs to be further evaluated. However, up-regulation of this particular circulatory miRNAmay serve as one of biomarker in PPRV infection for either disease progression as in the PPRV inflammatory responses or immunological suppression.

The interplay between virus and host need to be deciphered in depth to understand the viral pathogenesis. Most of the viruses lead to different immune systems modification as well immune evasions mechanisms that in place trigger the cancerous outputs(25). Most of the virus leads to apoptosis contributed by some the viral proteins, in our study the miRNAs level might increases with viral replication which leads to apoptosis. As the miR-21 were found to induce apoptosis in cells (26). Apoptosis has also been reported due to PPRV virus in infected tissue cells which leads to formation of apoptic bodies (27).microRNAs may be a powerful tool to compare within infected cell and noninfected cells, as altered miRNA expression may mark presence of viral infection. Micro RNAs in viral infections viz., in BVDV infection bta-miR-423 and miR-151-3p these two miRNA level found to be increased with infection, however they could only suggest as they could predict only timing of BVDV infection based on these miRNAs (28). In case of IBD viral infection, miR-130b found to be in support the viral replication and pathogenesis (29).In case of Marek's disease of chicken, miRNA gga-miR-15b downregulates in infected chicken and regulate expression of ATF2 (activating transcription factor) so as stop tumerogenesis (30).In foot and mouth disease of ruminant animals, miRNAs have been studied as biomarkers. miRNAs bta-miR-17-5p was elevated in acute infection while bta-miR-31 had highest expression in persistence of FMD (29), author suggested serum profiling of miRNAs to identify subclinical FMDV infection (31). 
However virus-host-miRNA interaction needs to be studied at deeper level to understand the specific markers and future targets for viral disease understanding. In our study we have assess only one miRNA which was upregulated in PPRV infection and is kind of circulatory miRNA whose signal was found to be very high in our studies as compared to other study where tissues have been taken for study. The serum miRNA are more stable than the tissues so this approach of hunt for novel miRNA in our PPRV study has better solution to identify the specific miRNAs. We predicted serum miR-21-3p may be used as indicator for stage of PPRV infection and as promising biomarker for PPRV disease progression.

In conclusion the present investigation we have evaluated the applicability of serum circulatory miR-21-3p expression profiling as potential biomarker for PPR progression in natural infected animals. However it need to be further validated in large cohort as wells as in experimental animals. It would be also important to investigate function of circulatory miR-21-3p in host immune response against PPRV infection so the definitive therapeutic targets may be identified for PPRV infection.

\section{Acknowledgements}

Authors are thankful to Associate Dean of Nagpur Veterinary College for providing necessary facilities for research work. The authors are grateful to Indian Council of Agricultural Research (ICAR), India and National Agriculture Science Fund (NASF) sponsored research project vide sanction order (F. No. NASF/ABA-6021/2017-18 Dated: 31.03.2017) for providing necessary funding for the research work.

Conflict of Interest: The authors declare that they have no known competing financial interests or personal relationships that could have appeared to influence the work reported in this paper.

\section{Supplementary File}

Supplementary figure 1. Gel-electrophoresis for Klebshiella species specific uge gene based PCR. (M-DNA ladder 50 bp; Samples: I5, I12, I18, I21; +ve-Postive control, -veNegative control).

\section{References}

1. Lin S.Y., Johnson S.M., Abraham M., Vella M.C., Pasquinelli A., Gamberi C., Gottlieb E and Slack F.J. (2004) The $C$ eleganshunchback homolog, hbl-1, controls temporal patterning and is a probable microRNA target. Dev. Cell.4:639-650

2. Chen, X., Ba, Y., Ma, L., Cai, X., Yin, Y., Wang, K., Guo, J., Zhang, Y., Chen, J., Guo, X. and Li, Q., (2008) Characterization of microRNAs in serum: a novel class of biomarkers for diagnosis of cancer and other diseases. Cell research, 18(10), p.997.

3. Mitchell, P.S., Parkin, R.K., Kroh, E.M., Fritz, B.R., Wyman, S.K., PogosovaAgadjanyan, E.L., Peterson, A., Noteboom, J., O'Briant, K.C., Allen, A. and Lin, D.W., (2008) Circulating microRNAs as stable blood-based markers for cancer detection. Proceedings of the National Academy of Sciences, 105(30), pp.10513-10518.

4. De Candia P., De Rosa V., Casiraghi M and Matarese G. (2016) Extracellular RNAs: a secret arm of immune system regulation. J BiolChem 291(14):7221-8.

5. Singh, R. P., Saravanan, P., Sreenivasa, B. P., Singh, R. K., \&Bandyopadhyay, S. K. (2004). Prevalence and distribution of peste des petitsruminants virus infection in small ruminants in India. Rev Sci 
Tech, 23(3), 807-819.

6. Cui JG., Li YY., Zhao Y., Bhattacharjee S and Lukiw WJ. (2010) Differential regulation of interleukin-1-receptorassociated kinase-1 (IRAK-1) and IRAK-2 by micro RNA-146a and NF- $\kappa \mathrm{B}$ in stressed human astroglial cells and in Alzheimer's disease. J. Biol. Chem;285:38951-38960.

7. Daiwile AP, Sivanesan S, Izzotti A, Bafana A, Naoghare PK, Arrigo P, Purohit HJ, Parmar D, Kannan K, 2015. Noncoding RNAs: possible players in the development of fluorosis. Biomed Research International, Vol. 2015, P. 1-11.

8. Tarale P, Daiwile A, SivanesanSD, Stöger R, Bafana A, Naoghare P, Parmar D, Chakrabarti T, Krishnamurthi K (2018) Manganese exposure: Linking downregulation of miRNA-7 and miRNA-433 with $\alpha$-synuclein overexpression and risk of idiopathic Parkinson's disease. Toxicology in Vitro (46), 94-101, http://dx.doi.org/10.1016/j.tiv.2017.10.003

9. Manjunath, S., Kumar, G. R., Mishra, B. P., Mishra, B., Sahoo, A. P., Joshi, C. G., Tiwari A.K.,Rajak K.K.,Janga S.C. (2015) Genomic analysis of host - Peste des petits ruminants vaccine viral transcriptome uncovers transcription factors modulating immune regulatory pathways. Vet. Res.46,15.

10.Pandey, A., Sahu, A.R., Wani, S.A., Saxena, S., Kanchan, S., Sah, V., Rajak, K.K., Khanduri, A., Sahoo, A.P., Tiwari, A.K. and Mishra, B., (2017) Modulation of Host miRNAsTranscriptome in Lung and Spleen of Peste des Petits Ruminants Virus Infected Sheep and Goats. Frontiers in microbiology, 8, p.1146.

11.Aher T., Roy A. and Kumar P. (2012) Molecular Detection of Virulence Genes Associated with Pathogenicity of KlebsiellasppIsolated from the Respiratory Tract of Apparently Healthy as well as Sick Goats Israel Journal of Veterinary
Medicine Vol. 67 (4).

12.Balamurugan, V, Sen A, Venkatesan, G. (2010) Application of semi-quantitative M gene-based hydrolysis probe (TaqMan) real-time RT-PCR assay for the detection of peste des petitis ruminants virus in the clinical samples for investigation into clinical prevalence of disease. Transbound Emerg Dis. 57 (6): 383-395.

13.Livak, K. J and Schmittgen T. D. (2001) Analysis of relative gene expression data using real-time quantitative PCR and the 2(-Delta Delta CT) Method. Methods 25, 402-408.

14.Lange T,Stracke S., Rettig R., Lendeckel U., Kuhn J., Schlüter R., Rippe V., Endlich K., Endlich N. (2017) Identification of miR-16 as an endogenous reference gene for the normalization of urinary exosomal miRNA expression data from CKD patients. PLoS One.;12(8):e0183435.

15.Trobaugh DW., Gardner CL., Sun C., Haddow AD., Wang E., Chapnik E, Mildner A., Weaver SC., Ryma KD and Klimstra WB(2014) RNA viruses can hijack vertebrate microRNAs to suppress innate immunity, Nature , 506(7487).2458.

16.Chang TC., Yu D, Lee YS, Wentzel EA, Arking DE, West KM, Dang CV, ThomasTikhonenko A, Mendell JT. (2008) Widespread microRNA repression by Myc contributes to tumorigenesis. Nat Genet. Jan; 40(1):43-50.

17.Roberts, A. P.,Lewis, A. P., and Jopling, C. L (2011)The role ofmicroRNAs in viral infection. Prog. Mol. Biol. Transl. Sci. 102,101-139.

18.Tahamtan A., Inchley C. S., Marzban M., Tavakoli-Yaraki M., Teymoori-Rad M., Nakstad B(2016) The role of microRNAs in respiratory viral infection: friend or foe? Rev. Med. Virol. 26.389-407.

19.Redova A., Poprach A., Nekvindova J., Iliev R., Radova L., Lakomy R., M.Svoboda., Vyzula R., and Slaby O. 
(2012) Circulating miR-378 and miR-451 in serum are potential biomarkers for renal cell carcinoma.J. Transl. Med.10.55.

20. TewodrosFentahun and MeleseWoldie (2012) Review on Peste Des Petits Ruminants (PPR) European Journal of Applied Sciences 4 (4): 160-167.

21.Chen Y., Chen J, Wang H, Shi J, Wu K, Liu S, (2013) HCV-induced miR-21 contributes to evasion of host immune system by targeting MyD88 and IRAK1. PLoSPathog (2013)9:e1003248.

22.Qiu X., Dong S., Qiao F., Lu S., Song Y., Lao Y. (2013) HBx-mediated miR-21 upregulation represses tumor-suppressor function of PDCD4 in hepatocellular carcinoma. Oncogene 32:32965.

23.Fukuhara T, Matsuura Y (2013) Role of miR-122 and lipid metabolism in HCV infection J Gastroenterol (2013)48:169176.

24.Damania, P., Sen, B., Dar, S. B., Kumar, S., Kumari, A and Gupta, E(2014). Hepatitis B Virus Induces Cell Proliferation via HBxInduced microRNA21 in Hepatocellular Carcinoma by Targeting Programmed Cell Death Protein4 (PDCD4) and Phosphatase and Tensin Homologue (PTEN) PLoS ONE 9(3): 91745

25.Jiang Jinmai, Lee EunJoo, GusevYuriy and Thomas D. Schmittgen (2005) Realtime expression profiling of microRNA precursors in human cancer cell lines. 5394-5403 Nucleic Acids Research. Vol. 33,No.17.
26.Lo, T. F., Tsai, W. C., and Chen, S. T. (2013) MicroRNA-21-3p, a berberineinduced miRNA, directly down-regulates human methionine adenosyltransferases $2 \mathrm{~A}$ and $2 \mathrm{~B}$ and inhibits hepatoma cell growth. PLoS ONE 8:e75628.

27.Mondal, B., Sreenivasa, B. P., Dhar, P., Singh, R. P.,andBandyopadhyay, S. K. (2001) Apoptosis induced by peste des petits ruminants virus in goat peripheral blood mononuclear cells. Virus Res. 73,113-119.

28.Taxis TM., Bauermann FV., Ridpath JF., Casas E (2017) Circulating MicroRNAs in Serum from Cattle Challenged with Bovine Viral Diarrhea Virus. Front Genet.2.8.91.

29.StenfeldtC., Arzt J., Smoliga G., LaRocco M., Gutkoska J., LawrenceP. (2017) Proof-of-concept study: profile of circulating microRNAs in bovine serum harvested during acute and persistent FMDV infection. Virol J (2017) 14(1).71.

30.TianFei,Zhang Huanmin, ChangShuang and SongJiuzhou (2012) MiRNA expression signatures induced by Marek's disease virus infection in chickens Genomics Volume 99, Issue 3, Pages 152159.

31.Williams David, Middleton Deborah, Wang Lin-Fa, Bean Andrew G.D \& Stewart Cameraon R. (2017) Circulating microRNA profiles of Hendra virus infection in Horses., Scientific Reports7:7431.

\section{How to cite this article:}

Preeti P. Bramhapurkar, Prabhakar A.Tembhurne, S. Chandra Sekar, D. Muthucheven, Sharvan Sehrawat, Prashant Tarale, Vijay.C.Ingle and Rajeev Kaul. 2020. Circulating MicroRNA-213p: A Potential Biomarker for Peste-des petits ruminants Virus in Naturally Infected Goats. Int.J.Curr.Microbiol.App.Sci. 9(08): 341-351. doi: https://doi.org/10.20546/ijcmas.2020.908.040 